\title{
Communication between health professionals and patients: review of studies using the RIAS (Roter Interaction Analysis System) method
}

Carla M. Pires ${ }^{1}$, Afonso M. Cavaco ${ }^{2 *}$

\section{Abstract}

Objective: Systematic review of studies that investigate the communication between patients and health professionals with the application of the RIAS methodology. Methods: Keyword Roter Interaction Analysis System was searched in the following bibliographic resources: Academic Search Complete, Current Contents, ISI Proceedings, PubMed, Elsevier, SpringerLink, Web of Science, RCAAP, Solo and the official RIAS site. Selection period: 2006 to 2011. Studies were selected using multicriteria dichotomous analysis and organized according to PRISMA.

Results: Identification of 1,262 articles (455 unrepeated). 34 articles were selected for analysis, distributed by the following health professions: family medicine and general practitioners (14), pediatricians (5), nurses (4), geneticists (3), carers of patients with AIDS (2), oncologists (2), surgeons (2), anesthetists (1) and family planning specialists (1). The RIAS is scarcely used and publicized within the scope of healthcare in Portuguese speaking countries.

Discussion: Main themes studied include the influence of tiredness, anxiety and professional burnout on communication and the impact of specific training actions on professional activities. The review enabled the identification of the main strengths and weaknesses of synchronous and dyadic verbal communication within the provision of healthcare.

Conclusion: Scientific investigation of the communication between health professionals and patients using RIAS has produced concrete results. An improvement is expected in health outcomes through the application of the RIAS.

Key words: RIAS, roter interaction analysis system, communication, health professionals.

\section{INTRODUCTION}

The Roter Interaction Analysis System (RIAS) is a computer-based methodology that permits to characterize the communication resulting from the interaction between health professionals and patients. ${ }^{1}$ The RIAS was initially based on the work of Robert Bales (1950) which, in the 1970s, was transposed to the investigation of the communication in medical consultations. In RIAS, communication units are identified (phrases, parts of phrases or single words) to which codes are associated, divided into two broad categories:
1. Affective and social, that is, codes related to the expression of concerns, approval/disapproval, agreement, criticism, empathy, etc.;

2. Instrumental, which includes codes related to the provision or verification of clinical and therapeutic information, among others, in the form of questions, paraphrases and affirmations. ${ }^{1,2}$

The RIAS coding system is applied to the dialog between a patient and a healthcare provider, recorded in an audio or vi- 
deo support. The RIAS categories are adapted to all stages of the medical consultation, from initial greetings, collection of objective and subjective information, as well as the phase of the patient, guidance and education, including other consultation components, for example, response to emotions and activation of the partnership with the patient. ${ }^{2,3}$

The RIAS method has been used in the United States and Europe in various healthcare and medical contexts, in observational and experimental studies, as well as in the pedagogic and educational contexts. Based on this methodology, it has been possible to characterize the communication in medical areas, such as primary care, gynecology, oncology, surgery, pediatrics and dentistry, as well as evaluating the results of educational interventions on physicians and patients. ${ }^{2}$ However, the research published on communication in primary healthcare is still limited, particularly in Portuguese, although communication research may contribute to relational improvements in general and family medicine during consultation. ${ }^{4}$ The publication and prompt use of tools validated for the diagnosis and evaluation of professional-patient communication in the consultation environment has not yet significantly contributed to the propagation and popularization of innovative methods that contribute to improve the relationship and care provided by health professionals. ${ }^{5}$

\section{Objective}

To systematically review publications and original works about communication studies involving health professionals and patients, with observational or experimental applications of the RIAS methodology, thereby illustrating the relevance of this tool and the underlying research area for the improvement of healthcare.

\section{Methods}

The review was conducted between October 2010 and February 2011 with the key-expression Roter Interaction Analysis System and/or RIAS, in the bibliographic resources described in Table 1. The first search was conducted without time limits and the summary of this search enabled the obtainment, among other data, of the main professional areas in which the RIAS studies were conducted. All of the original communication work using the RIAS and involving any health professionals in conventional medicine healthcare (e.g. physicians from different specialties, nurses, physiotherapists, etc.) were selected. The search was then limited to publications within the last 5 years (2006-2011), except for rare situations resulting from some professional areas, where studies involving the participation of at least 20 health professionals are scarce. In these cases, the 5 years period was counted from the date of the most recent study classified as relevant. This procedure permitted the identification of the most relevant articles at the time of the study within each specialty or professional area.

The search began on the official RIAS webpage (www. riasworks.com $)^{1}$, as this contains a systematized record of publications and information sources relating to works using this methodology. Next, databases and bibliographic sources were selected based on their relevance, in accordance with the area under study (health comunication) and the number of titles published annually (periodicals and e-books) (Table 1). The Database of Abstracts of Reviews of Effectiveness (DARE) was also consulted to confirm the existence of any RIAS related reviews, to avoid repetition as well as possible impairment of this work relevance. The literature search was updated in July 2013.

The literature selection criteria for this study were:

1. Having the RIAS methodology as the methodological basis;

2. Being an original work (observational or experimental);

3. Not being repeated record;

4. Having been published within the last 5 years (the time period was applied individually for each group of health professionals); and

5. Participation of at least 20 health professionals.

The search also included conference abstracts to expand the number of sources, giving a broader scope of the RIAS areas of research, while overcaming issues related with the last selection criteria. These criteria were defined in order to satisfy the objective of the present review. For example, the selection criteria included the number of health professionals to be at least 20 in order to select works with minimum methodological robustness. The articles selected for review were organized according to the PRISMA (Preferred Reporting Items for Systematic Reviews and Meta-Analyses $)^{6}$ method, which describes the items to be considered in systematic reviews and meta-analyses. Within this scope, the exclusion criteria were:

1. Studies written in a language other than Portuguese or English due to issues of an operational nature involving the translation of articles;

2. Articles or works which, although experimental in nature, were aimed at the investigation of very specific situations, such as studies on the specific impact of a determined socio-demographic characteristic (sex, age or ethnicity) in the relationship between health professional and patient; or

3. Studies to validate scales, operational methodologies or statistics, as they are outside of the current review 
context, whose general objective is to illustrate the areas and issues where the RIAS has demonstrated greater application and interest to study professional-patient communication.

The selected articles were carefully analyzed in relation to their content in the period from March 2011 to February 2012.

\section{RESULTS}

From a total of 1.262 articles, 34 articles were selected and distributed within the following health professionals: family medicine and general practitioners (14), pediatricians (5), nurses (4), geneticists (3), carers of patients with AIDS (2), oncologists (2), surgeons (2), anesthetists (1) and family planning specialists (1).

The number of studies excluded is described in Figure 1 and the number of articles selected by bibliographic resources is presented in Table 1 . No review was found in relation to the RIAS in the DARE. None of the studies selected were conducted in countries where Portuguese is the official language. A summary table of the articles selected for the systematic review can be found in Table 2 .

\begin{tabular}{|c|c|c|}
\hline Resource & Results & Selected \\
\hline Elsevier & 29 & 1 \\
\hline PubMed & 120 & 3 \\
\hline Solo & 145 & 6 \\
\hline RIASWORKS Website & 161 & 16 \\
\hline Highwire Press & 75 & 5 \\
\hline SCIRUS & 355 & 3 \\
\hline ISI Proceedings & 0 & 0 \\
\hline SpringerLink & 30 & 0 \\
\hline RCAAP & 4 & 0 \\
\hline DOAJ & 2 & 0 \\
\hline Web of Science & 119 & 0 \\
\hline SCIELO & 0 & 0 \\
\hline Academic Search Complete & 30 & 0 \\
\hline Willey Online & 30 & 0 \\
\hline Current Contents & 108 & 0 \\
\hline Annual Reviews & 12 & 0 \\
\hline OAlster & 42 & 0 \\
\hline TOTAL & 1.262 & 34 \\
\hline
\end{tabular}

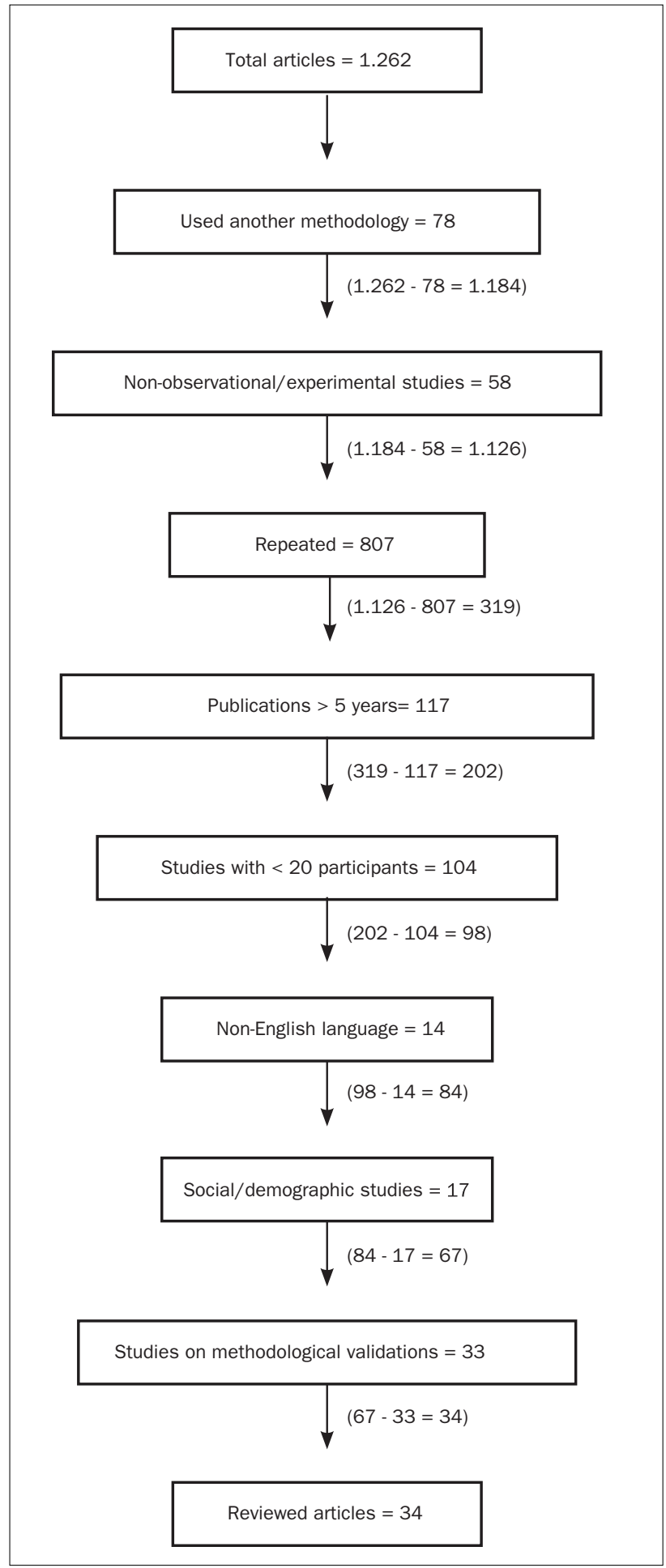

FIGURE 1 Results obtained after search of the bibliographic resources, with indication of the reason, the number of articles excluded, and the number of studies selected for the review. 
TABLE 2 Tabulated summary of selected articles for systematic review

\begin{tabular}{|c|c|c|c|c|c|c|}
\hline Citation & Objective & Venue & $N^{\circ} P$ & $\mathrm{~N}^{\circ} \mathrm{HP}$ & $\begin{array}{l}\text { Results, discussion and } \\
\text { conclusions* }\end{array}$ & Other observations \\
\hline & Family medicine & & & & & \\
\hline $\begin{array}{l}\text { Greer RC et al. } \\
(2010)^{7}\end{array}$ & $\begin{array}{l}\text { Evaluate the quality } \\
\text { of communication } \\
\text { about chronic } \\
\text { kidney disease in } \\
\text { primary care }\end{array}$ & $\begin{array}{l}\text { USA } \\
\text { (Baltimore, MD) }\end{array}$ & 236 & 40 & $\begin{array}{l}\text { - The physicians frequently used } \\
\text { technical terms ( } 28 \%, n=17) \text {. } \\
\text { - The comprehension of technical } \\
\text { terms by patients rarely was } \\
\text { confirmed by physicians }(2 \%, n=1) \text {. } \\
\text { - The discussion on chronic renal } \\
\text { disease was not frequent in } \\
\text { encounters. } \\
\text { - Ideally, these types of discussions } \\
\text { must be encouraged. } \\
\text { - The optimization of the } \\
\text { communication between patients } \\
\text { and physicians on these issues } \\
\text { might promote better health } \\
\text { outcomes. }\end{array}$ & $\begin{array}{l}\text { - } 15 \text { primary care practices. } \\
\text { - Hypertensive patients. Studies } \\
\text { with the enrollment of more } \\
\text { participants might be } \\
\text { desirable(conclusions are not } \\
\text { generalizable). }\end{array}$ \\
\hline $\begin{array}{l}\text { Beach MC et } \\
\text { al. } \\
(2006)^{8}\end{array}$ & $\begin{array}{l}\text { Evaluate the } \\
\text { attitudes of respect } \\
\text { between physicians } \\
\text { and patients }\end{array}$ & $\begin{array}{l}\text { USA } \\
\text { (Baltimore and } \\
\text { Washington, } \\
\text { DC) }\end{array}$ & 215 & 30 & $\begin{array}{l}\text { - The physicians' perception of } \\
\text { respect by patients was variable, } \\
\text { and was preferentially associated } \\
\text { with patients' familiarity. }\end{array}$ & $\begin{array}{l}\text { - Physicians rated their level of } \\
\text { respect by patients (after each } \\
\text { encounter).Questionnaire } \\
\text { (patients). }\end{array}$ \\
\hline $\begin{array}{l}\text { Haskard B et } \\
\text { al. } \\
(2008)^{9}\end{array}$ & $\begin{array}{l}\text { Investigate the } \\
\text { impact of a training } \\
\text { intervention on } \\
\text { communication }\end{array}$ & USA & $\begin{array}{l}2196 \\
\text { (Total } \\
\text { treated } \\
\text { patients) }\end{array}$ & 156 & $\begin{array}{l}\text { - This training aimed to improve } \\
\text { physicians' communication, and } \\
\text { stimulate the participation of the } \\
\text { patients. } \\
\text { - Patients' and physicians' } \\
\text { satisfaction might be improved with } \\
\text { this type of training. }\end{array}$ & $\begin{array}{l}\text { - Randomized experiment. } \\
\text { - Controlled trial. } \\
\text { - Groups: 1) physicians received } \\
\text { training; 2) patients received } \\
\text { training, and 3) both received } \\
\text { training. }\end{array}$ \\
\hline $\begin{array}{l}\text { Bensing } M \text { et } \\
\text { al. } \\
(2008)^{10}\end{array}$ & $\begin{array}{l}\text { To characterize the } \\
\text { verbal and } \\
\text { non-verbal } \\
\text { communication, } \\
\text { and possibly } \\
\text { patients' anxiety }\end{array}$ & Holland & $\begin{array}{l}2095 \\
(1388)\end{array}$ & 142 & $\begin{array}{l}\text { - The patients' concerns were not } \\
\text { directly expressed in more than a } \\
\text { half of the consultations, nor even } \\
\text { by patients with a higher level of } \\
\text { anxiety. } \\
\text { - General practitioners might } \\
\text { encourage patients to express their } \\
\text { concerns: verbally, or non-verbally } \\
\text { (e.g. showing more affect). }\end{array}$ & $\begin{array}{l}\text { - Patient direct gaze } \\
\text { (percentage). Questionnaire } \\
\text { (administered before } \\
\text { consultation). Patients' } \\
\text { subjective health, state anxiety, } \\
\text { and reason for encounter was } \\
\text { evaluated. }\end{array}$ \\
\hline
\end{tabular}


TABLE 2 Tabulated summary of selected articles for systematic review (continuation)

\begin{tabular}{|c|c|c|c|c|c|c|}
\hline Citation & Objective & Venue & $\mathbf{N}^{\circ} \mathbf{P}$ & $\mathrm{N}^{\circ} \mathrm{HP}$ & $\begin{array}{l}\text { Results, discussion and } \\
\text { conclusions* }\end{array}$ & Other observations \\
\hline $\begin{array}{l}\text { Mjaaland TA } \\
\text { et al. } \\
(2009)^{11}\end{array}$ & $\begin{array}{l}\text { Analyze the effects } \\
\text { of a communication } \\
\text { skills training for } \\
\text { general practitioners }\end{array}$ & Norway & 266 & 25 & $\begin{array}{l}\text { - The communication patterns } \\
\text { between general practitioners and } \\
\text { patients changed in some situations. }\end{array}$ & $\begin{array}{l}\text { - Communication skill training: } 40 \mathrm{~h} \\
\text { - Examples of skills: 1) obtain } \\
\text { indicators of the disease, such as } \\
\text { subjective symptoms of the } \\
\text { patient; 2) give an explanation to } \\
\text { the patient about their health } \\
\text { problems; 3) identify solutions } \\
\text { and resources, and 4) promote } \\
\text { appropriate behaviors. }\end{array}$ \\
\hline $\begin{array}{l}\text { Weingarten } \\
\text { MA et al. } \\
(2010)^{12}\end{array}$ & $\begin{array}{l}\text { Investigate the } \\
\text { nature of conflicts } \\
\text { between doctors } \\
\text { and patients } \\
\text { (primary care } \\
\text { encounters) }\end{array}$ & Israel & 291 & $28 / 56$ & $\begin{array}{l}\text { - } 40 \% \text { of consultations with cases of } \\
\text { conflicts ( } 21.2 \% \text { related to the } \\
\text { packages of health services/ } \\
\text { rationing). } \\
\text { - Conflictual encounters were } \\
\text { characterized by shorter opening } \\
\text { and closing phases. } \\
\text { - The physician showed a certain } \\
\text { duality in the management of } \\
\text { problems, because of the health } \\
\text { system demands } \\
\text { - The physicians' training might be } \\
\text { relevant in view of an adequate } \\
\text { managing conflict situations. }\end{array}$ & $\begin{array}{l}\text { - Videotape of } 291 \text { consultations } \\
\text { (28 general practitioners). } 7 \\
\text { focus groups with } 56 \text { general } \\
\text { practitioners (to collect } \\
\text { provider opinion about } \\
\text { conflicts). }\end{array}$ \\
\hline $\begin{array}{l}\text { Street JR et al. } \\
(2007)^{13}\end{array}$ & $\begin{array}{l}\text { Study of the } \\
\text { communication } \\
\text { style of physicians, } \\
\text { and their perception } \\
\text { about patients }\end{array}$ & $\begin{array}{l}\text { USA } \\
\text { (Houston, } \\
\text { Texas) }\end{array}$ & 207 & 29 & $\begin{array}{l}\text { - The doctors' communication was } \\
\text { more appropriated in relation to } \\
\text { the patients with a communication } \\
\text { more positive. } \\
\text { - Physicians might communicate } \\
\text { better with patients of certain } \\
\text { ethnic groups (possibility of bias). }\end{array}$ & $\begin{array}{l}\text { - } 10 \text { clinics (public or private). } \\
\text { - Possible limitations: small } \\
\text { sample size, non-evaluation of } \\
\text { patients' health condition, the } \\
\text { reason for the encounter, or } \\
\text { the specialty of physicians. }\end{array}$ \\
\hline $\begin{array}{l}\text { Bensing JM et } \\
\text { al. } \\
(2006)^{14}\end{array}$ & $\begin{array}{l}\text { Assessing the } \\
\text { variations on } \\
\text { communication } \\
\text { patterns between } \\
\text { general practitioners } \\
\text { and patients }\end{array}$ & Holland & $\begin{array}{l}102 / 108 \\
(1986 / 2002)\end{array}$ & $\begin{array}{l}27 / 108 \\
(1986 / 2002)\end{array}$ & $\begin{array}{l}\text { - No differences were found between } \\
\text { both patients' groups regarding sex } \\
\text { and age. } \\
\text { - In relation to the most recent data: } \\
\text { the general practitioners gave more } \\
\text { medical information and expressed } \\
\text { less concern about patients' health } \\
\text { conditions; patients were less active } \\
\text { (e.g. made less questions, and also } \\
\text { demonstrated less concerns). }\end{array}$ & $\begin{array}{l}\text { - Longitudinal study. } \\
\text { - Analysis of video tapes (general } \\
\text { practice consultations with } \\
\text { hypertensive patients). }\end{array}$ \\
\hline
\end{tabular}


TABLE 2 Tabulated summary of selected articles for systematic review (continuation)

\begin{tabular}{|c|c|c|c|c|c|c|}
\hline Citation & Objective & Venue & $N^{\circ} P$ & $N^{\circ} \mathrm{HP}$ & $\begin{array}{l}\text { Results, discussion and } \\
\text { conclusions* }\end{array}$ & Other observations \\
\hline $\begin{array}{l}\text { Van Den } \\
\text { Brink-Muinen } \\
\text { A et al. } \\
(2006)^{15}\end{array}$ & $\begin{array}{l}\text { Identify } \\
\text { communication } \\
\text { changes between } \\
\text { patients and general } \\
\text { practioners over } \\
\text { time } \\
\text { (about medical } \\
\text { treatment issues) }\end{array}$ & Holland & $\begin{array}{l}442 / 2784 \\
(1987 / \\
2001)\end{array}$ & $\begin{array}{l}16 / 142 \\
(1987 / \\
2001)\end{array}$ & $\begin{array}{l}\text { - In 2001: general practitioners } \\
\text { provided more information and } \\
\text { requested the patient involvement } \\
\text { in the decision-making process } \\
\text { more often, on the other hand this } \\
\text { providers checked less patients' } \\
\text { understanding. Excepting older } \\
\text { patients the involvement of patients } \\
\text { in medical decision-making was } \\
\text { higher in } 2001 .\end{array}$ & $\begin{array}{l}\text { - Questionnaire (pre and post } \\
\text { visit). Descriptive and } \\
\text { multivariate Analysis. }\end{array}$ \\
\hline $\begin{array}{l}\text { Zantinge M } \\
\text { et al. } \\
(2009)^{16}\end{array}$ & $\begin{array}{l}\text { Analyze if doctors' } \\
\text { burnout affect their } \\
\text { communication on } \\
\text { patients' mental } \\
\text { health problems, } \\
\text { and the duration of } \\
\text { consultations }\end{array}$ & Holland & $\begin{array}{l}1890 \\
\text { (consulta- } \\
\text { tions) }\end{array}$ & 126 & $\begin{array}{l}\text { - In the case of general practitioners } \\
\text { suffering from bunout neither their } \\
\text { attention on patients' psychological } \\
\text { problems nor their diagnosis were } \\
\text { affected.It was found that general } \\
\text { practitioners with more possibility } \\
\text { of exhaustion sometimes create } \\
\text { more opportunities to discuss the } \\
\text { mental health problems of patients. } \\
\text { General practitioners suffering from } \\
\text { burnout might benefit from training } \\
\text { (or coaching). }\end{array}$ & $\begin{array}{l}\text { - Nationally representative } \\
\text { sample of general practioners. } \\
\text { - Subscales of burnout: 1) } \\
\text { emotional exhaustion, 2) } \\
\text { depersonalization, or 3) } \\
\text { personal accomplishment. }\end{array}$ \\
\hline $\begin{array}{l}\text { Ratanawongsa } \\
\text { N et al. } \\
(2008)^{17}\end{array}$ & $\begin{array}{l}\text { Describe the } \\
\text { patient-physician } \\
\text { communication in } \\
\text { the case of } \\
\text { physicians' burnout }\end{array}$ & $\begin{array}{l}\text { USA } \\
\text { (Baltimore, MD) }\end{array}$ & 235 & 40 & $\begin{array}{l}\text { - The signs of physicians' professional } \\
\text { exhaustion did not affect } \\
\text { significantly:1) their attention with } \\
\text { the patient, 2) verbal dominance, 3) } \\
\text { the consultation length, and 4) the } \\
\text { levels of satisfaction or confidence } \\
\text { of the patients. } \\
\text { - The patients of doctors with more } \\
\text { serious problems gave twice } \\
\text { negative rapport-building } \\
\text { statements. }\end{array}$ & $\begin{array}{l}\text { - } 15 \text { clinics. } \\
\text { - Hypertensive patients were } \\
\text { enrolled in view of improving } \\
\text { their adherence. }\end{array}$ \\
\hline $\begin{array}{l}\text { Zantinge EM et } \\
\text { al. } \\
(2007)^{18}\end{array}$ & $\begin{array}{l}\text { Evaluate how the } \\
\text { workload of general } \\
\text { practitioners affect } \\
\text { their attention on } \\
\text { patients' } \\
\text { psychological } \\
\text { problems }\end{array}$ & Netherlands & $\begin{array}{l}2095 \\
\text { (consulta- } \\
\text { tions) }\end{array}$ & 142 & $\begin{array}{l}\text { - Physicians' professional exhaustion } \\
\text { was not significantly associated } \\
\text { with:1) patient-centeredness, 2) } \\
\text { verbal dominance, 3) the length of } \\
\text { consultation, and 4) patients' } \\
\text { satisfaction. The patients of doctors } \\
\text { with more serious problems gave } \\
\text { more negative rapport-building } \\
\text { statements. }\end{array}$ & $\begin{array}{l}\text { - } 2095 \text { videotaped consultations. } \\
\text { - The videotapes were from a } \\
\text { National survey (2000-2002). } \\
\text { - Eye contact was quantified (\%). }\end{array}$ \\
\hline
\end{tabular}


TABLE 2 Tabulated summary of selected articles for systematic review (continuation)

\begin{tabular}{|c|c|c|c|c|c|c|}
\hline Citation & Objective & Venue & No $P$ & $\mathrm{~N}^{\circ} \mathrm{HP}$ & $\begin{array}{l}\text { Results, discussion and } \\
\text { conclusions* }\end{array}$ & Other observations \\
\hline $\begin{array}{l}\text { Mjaaland TA } \\
\text { et al. } \\
(2009)^{19}\end{array}$ & $\begin{array}{l}\text { Investigate the use } \\
\text { of questions and } \\
\text { comments during } \\
\text { the consultations }\end{array}$ & $\begin{array}{l}\text { Norway } \\
\text { (Bærum) }\end{array}$ & 145 & 24 & $\begin{array}{l}\text { - In addition to RIAS, } 4 \text { new coding } \\
\text { categories were created to classify the } \\
\text { interactions of communication. } \\
\text { - } 2 \% \text { of the utterances were classified as } \\
\text { resource or coping oriented ( } 6 \\
\text { general practitioners were responsible } \\
\text { for } 59 \% \text { of these utterances). } \\
\text { - The general practitioners might be } \\
\text { more trained to cognitively manage } \\
\text { their interactions with patients. }\end{array}$ & $\begin{array}{l}\text { - Pilot Study. } \\
\text { - Additional categories: 1) } \\
\text { resources (e.g. general } \\
\text { practitioner comment something } \\
\text { positive), 2) coping (e.g. } \\
\text { comments/questions on the } \\
\text { managment of dificult health } \\
\text { situations), 3) attribution (e.g. } \\
\text { question/ comments discussing } \\
\text { patients' opinion about their own } \\
\text { situation), and 4) Solution- } \\
\text { focused techniques (e.g. use of } \\
\text { scales to classify a problem). }\end{array}$ \\
\hline \multirow[t]{2}{*}{$\begin{array}{l}\text { Van Den } \\
\text { Brink-Muinen } \\
\text { A et al. } \\
(2008)^{20}\end{array}$} & $\begin{array}{l}\text { Investigate patterns } \\
\text { of communication } \\
\text { in primary health } \\
\text { care (diverse } \\
\text { European countries) }\end{array}$ & $\begin{array}{l}\text { Estonia, Poland } \\
\text { and Romania }\end{array}$ & 1376 & 92 & $\begin{array}{l}\text { - It were found difference between the } \\
\text { patterns of communication of general } \\
\text { practitioners. Intercultural differences } \\
\text { should be taking into account during } \\
\text { the providers' eduction (e.g. } \\
\text { communication skills trainning). }\end{array}$ & $\begin{array}{l}\text { - Videotaped consultations } \\
\text { (doctor-patient). }\end{array}$ \\
\hline & Pediatrics & & & & & \\
\hline $\begin{array}{l}\text { Johnson KB et } \\
\text { al. } \\
(2008)^{21}\end{array}$ & $\begin{array}{l}\text { Evaluate the } \\
\text { parent-provider } \\
\text { communication } \\
\text { before and after the } \\
\text { introduction of a } \\
\text { computer-based } \\
\text { documentation tool } \\
\text { in consultations }\end{array}$ & USA & $\begin{array}{l}243 \\
\text { (consulta- } \\
\text { tions) }\end{array}$ & $149 / 94$ & $\begin{array}{l}\text { - Computer-based vs. control } \\
\text { consultations: duration slightly higher } \\
\text { ( } 32 \text { vs. } 27 \text { min); more open-ended } \\
\text { questions ( } 28 \% \text { vs. } 21 \% \text { ); > use of } \\
\text { partnership strategies; > use of } \\
\text { positive and social talk; more } \\
\text { patient-centered interactions; < use of } \\
\text { orienting and transition phrases. } \\
\text { - The quantity of dialogs (conversation) } \\
\text { was similar in both groups. } \\
\text { - The introduction of the computerized } \\
\text { system had a positive impact on the } \\
\text { communication between family and } \\
\text { providers. }\end{array}$ & $\begin{array}{l}\text { - Pediatrics residents. The audio } \\
\text { recordings were coded. One } \\
\text { control group: } 149 \text { consultations } \\
\text { were not computer-based } \\
\text { (control group), and } 94 \\
\text { consultations were computer- } \\
\text { based. }\end{array}$ \\
\hline $\begin{array}{l}\text { Hart } N \text { et al. } \\
(2006)^{22}\end{array}$ & $\begin{array}{l}\text { Evaluating } \\
\text { parent-provider } \\
\text { communication } \\
\text { after a training }\end{array}$ & USA & $\begin{array}{l}92 \\
\text { (consulta- } \\
\text { tions) }\end{array}$ & 28 & $\begin{array}{l}\text { - } 28 \text { residents. The consultations }(92) \\
\text { were audio-taped. } \\
\text { - Parents were significantly more } \\
\text { satisfied ( } \mathrm{p}<0.05 \text { ), and providers use } \\
\text { more interpersonal communication } \\
\text { after the training intervention. } \\
\text { - Residents' training on } \\
\text { communication skills may contribute } \\
\text { to increas parents' satisfaction of } \\
\text { parents. }\end{array}$ & $\begin{array}{l}\text { - } 3 \text { consultations: } 1 \text { before and } 2 \\
\text { after the residents' training. }\end{array}$ \\
\hline
\end{tabular}


TABLE 2 Tabulated summary of selected articles for systematic review (continuation)

\begin{tabular}{|c|c|c|c|c|c|c|}
\hline Citation & Objective & Venue & No $P$ & $N^{\circ} \mathrm{HP}$ & $\begin{array}{l}\text { Results, discussion and } \\
\text { conclusions* }\end{array}$ & Other observations \\
\hline $\begin{array}{l}\text { Wissow L et al. } \\
(2011)^{23}\end{array}$ & $\begin{array}{l}\text { Determining } \\
\text { indicators to predict } \\
\text { parent and child } \\
\text { outcomes after a } \\
\text { mental health } \\
\text { training }\end{array}$ & $\begin{array}{l}\text { USA } \\
\text { (Baltimore, MD, } \\
\text { Washington, DC } \\
\text { and New York) }\end{array}$ & 403 & 50 & $\begin{array}{l}\text { - Providers who received training on } \\
\text { mental care were more patient- } \\
\text { centerd, and presented more } \\
\text { appropriate characteristics of } \\
\text { communication. The consultations } \\
\text { more family-centered were } \\
\text { predictive of an improvement on } \\
\text { children and adolescents mental } \\
\text { symptoms. }\end{array}$ & $\begin{array}{l}\text { - Children and adolescents with } \\
\text { emotional and behavioral } \\
\text { problems ( } 5 \text { to } 16 \text { years). } 50 \\
\text { providers: trained in pediatrics } \\
\text { (68\%), or family practice (30\%). } \\
\text { - } 15 \text { primary care offices. }\end{array}$ \\
\hline $\begin{array}{l}\text { Liu CC et al. } \\
(2008)^{24}\end{array}$ & $\begin{array}{l}\text { How working until } \\
\text { late might in } \\
\text { influence residents' } \\
\text { communication/ } \\
\text { performance } \\
\text { in the consultations } \\
\text { of the following day }\end{array}$ & USA & $\begin{array}{l}243 \\
\text { (primary } \\
\text { care visits) }\end{array}$ & 52 & $\begin{array}{l}\text { - Residents who stay working until } \\
\text { late were more verbally dominant, } \\
\text { and less patient centered. } \\
\text { - Implications: it is required a better } \\
\text { management of profissional } \\
\text { performance in case of fatigue. }\end{array}$ & - Teaching hospital. \\
\hline \multirow[t]{2}{*}{$\begin{array}{l}\text { Greenley RN et } \\
\text { al. } \\
(2006)^{25}\end{array}$} & $\begin{array}{l}\text { Analyze the stability } \\
\text { of parents' } \\
\text { understanding of } \\
\text { the random } \\
\text { assignment in } \\
\text { childhood leukemia } \\
\text { trials }\end{array}$ & USA & 84 & $\begin{array}{l}\text { Not } \\
\text { applicable } \\
\text { (only } \\
\text { patients' } \\
\text { interviews) }\end{array}$ & $\begin{array}{l}\text { - } 49 \% \text { of parents failed to understand } \\
\text { the random assignment. Favorable } \\
\text { factors related to parents' } \\
\text { understanding: majority ethnicity, } \\
\text { high socioeconomic status, } \\
\text { provider-patient communication, } \\
\text { and the presence of nurses during } \\
\text { the consultation. } \\
\text { - Implications: Further studies are } \\
\text { advisable (in different geographical } \\
\text { locations and clinical contexts). }\end{array}$ & $\begin{array}{l}\text { - Pediatric Hospitals. } \\
\text { - Limitations: only urban areas } \\
\text { and academic centers, small } \\
\text { sample size, informational } \\
\text { materials not evaluated, and } \\
\text { the parents' understanding } \\
\text { only was checked at two points } \\
\text { (48 h and } 6 \text { months later). }\end{array}$ \\
\hline & Nursing & & & & & \\
\hline $\begin{array}{l}\text { Sheldon LK et } \\
\text { al. } \\
(2009)^{3}\end{array}$ & $\begin{array}{l}\text { Analyze nurse } \\
\text { responsiveness to } \\
\text { cancer patient } \\
\text { expressions of } \\
\text { emotion }\end{array}$ & USA & $\begin{array}{l}\text { Simulated } \\
\text { patients }\end{array}$ & 74 & $\begin{array}{l}\text { - The simulated patients' expressions of } \\
\text { sadness elicited a superior affective } \\
\text { responses (e.g. concern, approval, } \\
\text { empathy and concordance) than } \\
\text { anger. The simulated patients' } \\
\text { expressions of neutrality and anger } \\
\text { elicited a superior instrumental } \\
\text { behaviors in professionals (e.g. orient, } \\
\text { check, opinion about the therapy) } \\
\text { than sadness. Age, work stress, and } \\
\text { professional experience were variables } \\
\text { significantly correlated. } \\
\text { - This methodology was considered } \\
\text { convenient to training communication } \\
\text { skills by the majority of nurses. }\end{array}$ & $\begin{array}{l}\text { - } 8 \text { sites (e.g. oncology services). } \\
\text { - The simulated expressions were: } \\
\text { 1) anger, 2) sadness, and 3) } \\
\text { neutrality. }\end{array}$ \\
\hline
\end{tabular}




\section{TABLE 2 Tabulated summary of selected articles for systematic review (continuation)}

\begin{tabular}{|c|c|c|c|c|c|c|}
\hline Citation & Objective & Venue & $N^{\circ} P$ & $N^{\circ} \mathrm{HP}$ & $\begin{array}{l}\text { Results, discussion and } \\
\text { conclusions* }\end{array}$ & Other observations \\
\hline $\begin{array}{l}\text { Gilbert DA et } \\
\text { al. } \\
(2009)^{26}\end{array}$ & $\begin{array}{l}\text { Investigate } \\
\text { patient-nurse } \\
\text { communication, and } \\
\text { variations in } \\
\text { outcomes }\end{array}$ & $\begin{array}{l}\text { USA } \\
\text { (New England) }\end{array}$ & 155 & 31 & $\begin{array}{l}\text { - Better outcomes were obtained in the } \\
\text { case of: older patients with less } \\
\text { previous medical and social } \\
\text { assistance, nurses with previous } \\
\text { longer professional experience, the } \\
\text { encounters with higher biomedical } \\
\text { and psychosocial information, or } \\
\text { predominance of positive dialogs (e.g. } \\
\text { expressing reassurance or optimism). }\end{array}$ & $\begin{array}{l}\text { - Studies in view of improving } \\
\text { communication on lifestyle are } \\
\text { needed. }\end{array}$ \\
\hline $\begin{array}{l}\text { Langewitz W et } \\
\text { al. } \\
(2010)^{27}\end{array}$ & $\begin{array}{l}\text { Studying the impact } \\
\text { of a training on the } \\
\text { communication } \\
\text { between the nurses } \\
\text { and simulated } \\
\text { oncologic patients }\end{array}$ & Switzerland & $\begin{array}{l}\text { Simulated } \\
\text { patients }\end{array}$ & 70 & $\begin{array}{l}\text { - There was a statiscally significant } \\
\text { increase regarding the statements: } \\
\text { appropriate empathic ( } 1.6 \% \text { vs. } 3.2 \%) \text {, } \\
\text { reassuring ( } 2.3 \% \text { vs. } 3.4 \%) \text {, questions } \\
\text { concerning psychosocial information } \\
\text { ( } 2.8 \% \text { vs. } 4.0 \%) \text {. } \\
\text { - On the other hand biomedical } \\
\text { utterances: } 17.8 \% \text { vs. } 13.3 \% \text { (nurses) } \\
\text { and } 8.1 \% \text { vs. } 6.7 \% \text { (patients) } \\
\text { decreased. }\end{array}$ & $\begin{array}{l}\text { - The training was advertized by } \\
\text { email. The patient centeredness } \\
\text { was assessed based on the type } \\
\text { and duration of dialogs } \\
\text { (between health professionals } \\
\text { and simulated patients). } \\
\text { - Video record of interviews } \\
\text { (pre- and post-intervention). } \\
\text { - Only } 61 \text { video recordings were } \\
\text { analyzed. }\end{array}$ \\
\hline $\begin{array}{l}\text { Kim YM et al. } \\
(2008)^{28}\end{array}$ & $\begin{array}{l}\text { Identifying factors } \\
\text { that contribute to } \\
\text { increase the } \\
\text { effectiveness } \\
\text { communication } \\
\text { between nurses and } \\
\text { patients }\end{array}$ & $\begin{array}{l}\text { Indonesia } \\
\text { (Java) }\end{array}$ & 768 & 64 & $\begin{array}{l}\text { - More effective communication in } 32 \\
\text { patients ( } 4.2 \% \text { of } 768 \text { ) and } 7 \\
\text { providers ( } 10.9 \% \text { of } 64) \text {. Example of } \\
\text { additional measures: better } \\
\text { management of patients flow and } \\
\text { media campaigns. }\end{array}$ & $\begin{array}{l}\text { - } 64 \text { clinics (randomized). } \\
\text { - Qualitative interviews with } \\
\text { collection of individual and } \\
\text { profissional data (e.g. number of } \\
\text { years of professional experience). } \\
\text { - Potential sources of bias: social } \\
\text { correct responses, or mood states } \\
\text { (from patients or providers). } \\
\text { - Limitations: only } 1 \text { consultation, } \\
\text { translation of the audio recording } \\
\text { of the consultation to English (for } \\
\text { application of RIAS) with possible } \\
\text { compromise of texts integrity, and } \\
\text { a reduced number of evaluations. }\end{array}$ \\
\hline
\end{tabular}

(continue) 
TABLE 2 Tabulated summary of selected articles for systematic review (continuation)

\begin{tabular}{|c|c|c|c|c|c|c|}
\hline Citation & Objective & Venue & No $P$ & $\mathrm{~N}^{\circ} \mathrm{HP}$ & $\begin{array}{l}\text { Results, discussion and } \\
\text { conclusions* }\end{array}$ & Other observations \\
\hline & Geneticists & & & & & \\
\hline $\begin{array}{l}\text { Roter DL et al. } \\
(2009)^{29}\end{array}$ & $\begin{array}{l}\text { Observe how the } \\
\text { complexity of } \\
\text { genetic counseling } \\
\text { sessions are related } \\
\text { with the learning of } \\
\text { genetic-related } \\
\text { information by low } \\
\text { literate participants }\end{array}$ & USA & $\begin{array}{l}\text { Simulated } \\
\text { patients }\end{array}$ & 96 & $\begin{array}{l}\text { - } 312 \text { participants observed videos of } \\
\text { genetic consultations. The genetic } \\
\text { informations learned by participants } \\
\text { were assessed. Highly technical terms/ } \\
\text { dialogs represent an obstacle for } \\
\text { individuals of lower literacy. However } \\
\text { these obstacules were smaller, in the } \\
\text { case of the sessions with more dialogs/ } \\
\text { interactivity. } \\
\text { - It is advisable that the genetic } \\
\text { counselor communicate in a suitable } \\
\text { manner, especially with low literate } \\
\text { patients. }\end{array}$ & $\begin{array}{l}\text { - } 79 \text { video sessions of prenatal } \\
\text { counseling were observed by a } \\
\text { total of } 312 \text { participants. } \\
\text { - } 9 \text { simulated patients. The genetic } \\
\text { counselors were recruited through } \\
\text { the National Society of Genetic } \\
\text { Counselors. } \\
\text { - The number of words related to } \\
\text { genetic terms were quantified. }\end{array}$ \\
\hline $\begin{array}{l}\text { Roter DL et al. } \\
(2007)^{30}\end{array}$ & $\begin{array}{l}\text { Assessing the impact } \\
\text { associated with the } \\
\text { complexity of the } \\
\text { genetic counseling } \\
\text { sessions }\end{array}$ & USA & $\begin{array}{l}\text { Simulated } \\
\text { clients }\end{array}$ & 152 & $\begin{array}{l}\text { - Sessions with a high porportion of } \\
\text { technical terms were associated with } \\
\text { short sessions, less interactive dialogs, } \\
\text { and less satisfied simulated clients. } \\
\text { - The opinion of the simulated client on } \\
\text { the information provided by the } \\
\text { genetic counselor is inversely related } \\
\text { with the use of technical terms. }\end{array}$ & $\begin{array}{l}\text { - Audio and video recording (152 } \\
\text { sessions on pre-natal, and cancer } \\
\text { counseling). } \\
\text { - It was evalutated: 1) the use of } \\
\text { technical terms, 2) the complexity } \\
\text { of language (use of the Microsoft } \\
\text { Word grammar), and } 3 \text { ) the } \\
\text { structural characteristics of } \\
\text { dialogs (RIAS). }\end{array}$ \\
\hline $\begin{array}{l}\text { Roter D et al. } \\
(2006)^{31}\end{array}$ & $\begin{array}{l}\text { Identify patterns of } \\
\text { communication in } \\
\text { genetic counseling } \\
\text { sessions: teaching vs. } \\
\text { counseling }\end{array}$ & USA & $\begin{array}{l}\text { Simulated } \\
\text { clients }\end{array}$ & 152 & $\begin{array}{l}\text { - Identification of } 4 \text { communication } \\
\text { patterns: } 2 \text { teaching patterns and } 2 \\
\text { counseling patterns. } \\
\text { - The genetic counselor were more } \\
\text { verbally dominant (i.e. using greater } \\
\text { conversation times) in the teaching } \\
\text { patterns. }\end{array}$ & $\begin{array}{l}\text { - Questionnaires: 1) simulated } \\
\text { clients (to collect data on their } \\
\text { opinion about the genetic } \\
\text { counselor, and on their } \\
\text { satisfaction with the verbal and } \\
\text { non-verbal communication of the } \\
\text { genetic counselor), and 2) } \\
\text { genetic counselors (to collect } \\
\text { demographic data, and their } \\
\text { perception about interpersonal } \\
\text { relationship with the client } \\
\text { simulated and opinion about the } \\
\text { realism of the session). }\end{array}$ \\
\hline
\end{tabular}


TABLE 2 Tabulated summary of selected articles for systematic review (continuation)

\begin{tabular}{|c|c|c|c|c|c|c|}
\hline Citation & Objective & Venue & $\mathbf{N}^{\circ} \mathrm{P}$ & $\mathrm{N}^{\circ} \mathrm{HP}$ & $\begin{array}{l}\text { Results, discussion and } \\
\text { conclusions* }\end{array}$ & Other observations \\
\hline & Aids care & & & & & \\
\hline $\begin{array}{l}\text { Kumar R et al. } \\
(2010)^{32}\end{array}$ & $\begin{array}{l}\text { Explore how the } \\
\text { communication } \\
\text { between patients } \\
\text { with HIV and health } \\
\text { providers might } \\
\text { influence patients' } \\
\text { decisions }\end{array}$ & $\begin{array}{l}\text { USA } \\
\text { (Baltimore, } \\
\text { Detroit, New } \\
\text { York and } \\
\text { Portland) }\end{array}$ & 434 & 45 & $\begin{array}{l}\text { - In relation to patients: } 72 \% \text { preferred } \\
\text { to share decisions, } 23 \% \text { preferred that } \\
\text { the provider take de decision alone, } \\
\text { and } 5 \% \text { preferred to take their own } \\
\text { decisions. } \\
\text { - Patients who prefer that the } \\
\text { professional decide alone are less } \\
\text { likely: to manifest symptoms of } \\
\text { depression, to understand providers' } \\
\text { explanations. Might be considered a } \\
\text { more appropriate approach when the } \\
\text { health professional involves patients } \\
\text { in the decision making process. }\end{array}$ & $\begin{array}{l}\text { - Health professionals: doctors } \\
\text { and nurses. Patients were } \\
\text { questioned about their role in } \\
\text { relation to the medical decions. }\end{array}$ \\
\hline $\begin{array}{l}\text { Beach CM et al. } \\
(2010)^{33}\end{array}$ & $\begin{array}{l}\text { Impact of a training } \\
\text { administered to } \\
\text { health professionals } \\
\text { of HIV patients (on } \\
\text { medication } \\
\text { adherence). }\end{array}$ & USA & 140 & 24 & $\begin{array}{l}\text { - The training produced a positive } \\
\text { impact on communication about } \\
\text { medication adherence. } \\
\text { - Differences (before and after } \\
\text { training): more dialogs on } \\
\text { therapeutic regims ( } p=0.003) \text {, } \\
\text { more positive dialogs }(p=0.039) \text {, } \\
\text { more emotional dialogs }(p<0.001) \text {, } \\
\text { more questions on patients' } \\
\text { opinion ( } p=0.009) \text {, and discussions } \\
\text { about adherence }(p=0.026) \text {. }\end{array}$ & $\begin{array}{l}\text { - Providers from } 3 \text { care sites. } \\
\text { - HIV patients. } \\
\text { - Conference abstract. }\end{array}$ \\
\hline & Oncology & & & & & \\
\hline $\begin{array}{l}\text { Daugherty } C \text { et } \\
\text { al. } \\
(2009)^{34}\end{array}$ & $\begin{array}{l}\text { Characterize the } \\
\text { communication } \\
\text { between oncologists } \\
\text { and patients with } \\
\text { advanced cancer in } \\
\text { relation to the } \\
\text { understanding of } \\
\text { the informed } \\
\text { consent (phase I } \\
\text { clinical trials) }\end{array}$ & USA & 131 & 25 & $\begin{array}{l}\text { - Other treatment options were } \\
\text { discussed by physicians in } 47 \% \text { of the } \\
\text { encounters. } \\
\text { - The option of not performing any } \\
\text { treatment was reported by the } \\
\text { physician in } 29 \% \text { of encounters. } \\
\text { - The terms "death" and "terminal" } \\
\text { were used by the physician in } 5.8 \% \text { of } \\
\text { the encounters. } \\
\text { - The communication on alternative } \\
\text { treatments, or prognosis was not } \\
\text { considered adequate. }\end{array}$ & - Conferváceo abstract. \\
\hline
\end{tabular}


TABLE 2 Tabulated summary of selected articles for systematic review (continuation)

\begin{tabular}{|c|c|c|c|c|c|c|}
\hline Citation & Objective & Venue & $\mathbf{N}^{\circ} \mathrm{P}$ & $N^{\circ} \mathrm{HP}$ & $\begin{array}{l}\text { Results, discussion and } \\
\text { conclusions* }\end{array}$ & Other observations \\
\hline \multirow[t]{2}{*}{$\begin{array}{l}\text { Siminoff LA et } \\
\text { al. } \\
(2006)^{35}\end{array}$} & $\begin{array}{l}\text { Patterns of } \\
\text { communication in } \\
\text { consultations } \\
\text { (patients with breast } \\
\text { cancer) }\end{array}$ & USA & 405 & 58 & $\begin{array}{l}\text { - In this study physicians spend more } \\
\text { time communicating with the } \\
\text { patients more educated and young, } \\
\text { as well as with the patients of higher } \\
\text { income level.These discrepancies in } \\
\text { communication might influence } \\
\text { patients' health outcomes. } \\
\text { - The discussions on psychosocial } \\
\text { issues such as how patients deal } \\
\text { with their diagnosis, and patients' } \\
\text { feelings were limited. } \\
\text { - The way how providers } \\
\text { communicated was different } \\
\text { depending of the patients' } \\
\text { sociocultural characteristics. } \\
\text { - Specific training on how to deal } \\
\text { with these differences might be } \\
\text { useful to patients, and providers. }\end{array}$ & - 14 practices (two states). \\
\hline & Surgery & & & & & \\
\hline $\begin{array}{l}\text { Levinson W et } \\
\text { al. } \\
(1997)^{36^{*}}\end{array}$ & $\begin{array}{l}\text { Relate the } \\
\text { communication } \\
\text { with malpractice } \\
\text { claims }\end{array}$ & $\begin{array}{l}\text { USA } \\
\text { (Oregon and } \\
\text { Colorado) }\end{array}$ & $\begin{array}{l}10 \\
\text { clinics per } \\
\text { doctor }\end{array}$ & 124 & $\begin{array}{l}\text { - Two groups: primary care } \\
\text { physicians, and surgeons. } \\
\text { - Primary care physicians with } \\
\text { no-claims registered: more } \\
\text { statements of orientation, laughed } \\
\text { more, requested more patients' } \\
\text { opinion, confirmed more patients' } \\
\text { understanding, and encouraged } \\
\text { more the dialoge comparatively to } \\
\text { the primary care physicians with } \\
\text { complaints, as well as their } \\
\text { consultations were more longer } \\
\text { (18.3 vs. } 15 \text { minutes). } \\
\text { - It were not found different } \\
\text { communication characteristics } \\
\text { between surgeons with claims, or } \\
\text { no-claims. }\end{array}$ & $\begin{array}{l}\text { - In view of avoiding claims the } \\
\text { implementation of good } \\
\text { communication practices is } \\
\text { advisable. }\end{array}$ \\
\hline $\begin{array}{l}\text { Levinson } W \text { et } \\
\text { al. } \\
(1999)^{37^{*}}\end{array}$ & $\begin{array}{l}\text { Characterize the } \\
\text { communication } \\
\text { between surgeons } \\
\text { and patients in } \\
\text { routine } \\
\text { consultations }\end{array}$ & USA & $\begin{array}{l}676 \\
\text { (routine } \\
\text { visits) }\end{array}$ & $\begin{array}{l}66 \\
(29 / 37)\end{array}$ & $\begin{array}{l}\text { - } 29 \text { general surgeons and } 37 \\
\text { orthopaedic surgeons. Social } \\
\text { conversations, or the discussion of } \\
\text { patients' problems was limited. } \\
\text { - Further investigations are } \\
\text { recommended to understand the } \\
\text { influence of surgeons' } \\
\text { communication on patient behavior. }\end{array}$ & $\begin{array}{l}\text { - Possible limitations: limited } \\
\text { number of topics discussed in } \\
\text { this type of consultations }\end{array}$ \\
\hline
\end{tabular}


TABLE 2 Tabulated summary of selected articles for systematic review (continuation)

\begin{tabular}{|c|c|c|c|c|c|c|}
\hline Citation & Objective & Venue & $\mathbf{N}^{\circ} \mathrm{P}$ & $\mathrm{N}^{\circ} \mathrm{HP}$ & $\begin{array}{l}\text { Results, discussion and } \\
\text { conclusions* }\end{array}$ & Other observations \\
\hline & Anesthesia & & & & & \\
\hline \multirow[t]{2}{*}{$\begin{array}{l}\text { Kindler } \mathrm{CH} \text { et al. } \\
(2005)^{38^{*}}\end{array}$} & $\begin{array}{l}\text { Quantitative Analysis } \\
\text { of the } \\
\text { communication } \\
\text { between the } \\
\text { anesthetist and the } \\
\text { patient in } \\
\text { preoperative } \\
\text { consultation }\end{array}$ & $\begin{array}{l}\text { Switzerland } \\
\text { (Basel) }\end{array}$ & 57 & 57 & $\begin{array}{l}\text { - Duration of visit: } 16.1 \text { min (average). } \\
\text { - The number of utterances per } \\
\text { patient/anaesthesist, and the } \\
\text { duration of the consultations were } \\
\text { not influenced by gender. \% of } \\
\text { utterances/consultation: } \\
\text { anaesthesists ( } 53.5 \% \text { ) and patients } \\
\text { ( } 46.5 \%) \text {. } \\
\text { - Anaesthetists: < } 0.1 \% \text { utterances } \\
\text { related with psychosocial issues } \\
\text { (dialogs mainly related with } \\
\text { biomedical issues). } \\
\text { - The use of open questions and } \\
\text { emotional statements by these } \\
\text { providers were positively related with } \\
\text { the patients' involvment. }\end{array}$ & $\begin{array}{l}\text { - The discussions on biomedical, } \\
\text { and psychosocial issues were } \\
\text { quantified (number of } \\
\text { utterances). }\end{array}$ \\
\hline & Family planning & & & & & \\
\hline $\begin{array}{l}\text { Abdel-Tawab N } \\
\text { et al. } \\
(2002)^{39^{*}}\end{array}$ & $\begin{array}{l}\text { Investigate the } \\
\text { importance of } \\
\text { client-centered } \\
\text { communication in } \\
\text { consultations of } \\
\text { family planning }\end{array}$ & Egypt & $\begin{array}{l}112 \\
\text { (clients) }\end{array}$ & 34 & $\begin{array}{l}\text { - The communication was physician- } \\
\text { centered in } 2 / 3 \text { of consultations. } \\
\text { - Client-centered consultations were } \\
\text { one minute longer than physician- } \\
\text { centered consultations. } \\
\text { - Client-centered consultations were } \\
\text { associated with great satisfaction, } \\
\text { and adherence. } \\
\text { - The interruption of the } \\
\text { contraceptive method was } \\
\text { associated with more physicians' } \\
\text { disagreement statements. } \\
\text { - Similarly to what happen in } \\
\text { developed countries, client- } \\
\text { centered models are more } \\
\text { advantageous than physician- } \\
\text { centered models. }\end{array}$ & $\begin{array}{l}\text { - Home visits to confirm clients' } \\
\text { contraceptive adherence (at } 3 \\
\text { and } 7 \text { months). }\end{array}$ \\
\hline
\end{tabular}

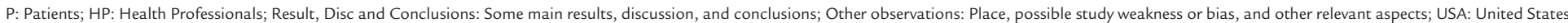
of America. * Studies selected not according to the study period.

The distribution of the studies selected by year of publication was as follows: 1997 (1), 1999 (1), 2002 (1), 2005 (1), 2006 (7), 2007 (3), 2008 (7), 2009 (7), 2010 (4), and 2011 (1). Four studies were dated before 2006 , taking into account that the participation of at least 20 health professionals was not found in the areas of surgery (1997 and 1999), ${ }^{36,37}$ anesthesia (2005), ${ }^{38}$ and family planning (2002). ${ }^{39}$
Two of the references selected corresponded to abstracts from conferences. For illustration purposes only, all articles were published in periodicals with an average impact factor (IF) per year and per specialty as follows: surgery (5.801), pediatrics (5.151), geneticists (2.866), patients with AIDS (2.654), anesthesia (2.512), primary care (2.447), nurses (1.961), family planning (1.931) and oncology (1.778). 


\section{Discussion}

Given the results of this review, the identification of RIAS studies was found amongst various groups of health professionals (Table 2) as well as confirmed the absence of works in Portuguese, both in the collection of field data or written publications.

The studies exemplify the investigation of verbal, synchronous and one-on-one (or dyadic) communication between professionals and patients, through the application of the RIAS methodology which, in some cases, was also associated with nonverbal behavior recording techniques. Taking into account the different professional areas studied, the total number of health professionals were superior to 2500 and the average IF of 3.11 of the selected articles, it is possible to consider the results obtained from this bibliographic review of sufficient interest for elucidating, albeit briefly, the contribution of the RIAS methodology for the processes analysis in interindividual communication in healthcare.

The selection criteria used in this review did not enable other professional areas or specialties studied by the RIAS to be selected, such as intensive care, mental and palliative care, dentistry, medical emergencies, prenatal diagnosis, hospitalization, medicine in adolescence, ophthalmology and radiotherapy. Even so, the boundaries imposed by the search criteria enable interesting data to be obtained, such as studies with a sample size of health professionals enough for aprooaching statistical representation. In the specific case of the RIAS, although a computer software, currently used on a global scale, ${ }^{1}$ its application does not seem to be extensive, i.e. sufficient to represent the entire professional group under analysis. In fact, the possibility of coding and analyzing a large volume of data in a short time is one of the main advantages of the RIAS when compared with other methodologies for studying communication. This suggests, in the majority of cases, that results to be reproducible or extendable beyond small samples, which was impossible to prove in this review. In addition, there is a limited use of this method by health organizations and institutions in other areas of healthcare, beyond medical practice.

The RIAS has been useful for helping to establish causal links between verbal components of professionals' communication and the patients' health outcomes. Examples of these causal models are the relationships between some RIAS codes and satisfaction, adherence to treatment, level of control and patient knowledge about their pathologies. ${ }^{3,26,32,34,35}$ As could be expected, the instrumental codes showed to be most important in the evaluation of technical aspects of the consultation,,$^{7,29,30}$ and the af- fective categories were shown to be most preponderant in the evaluation of patient satisfaction. ${ }^{8,9}$ To fully interpret these last categories of RIAS codes it is also important to evaluate the nonverbal components, such as intonation, words and type of voice used by speakers. ${ }^{10,41}$

The literature describes various mathematical relationships between different RIAS coding units, using formulas that result in composite variables or even constructs that describe linguistic and behavioral structures of the communication, such as patient-centeredness. ${ }^{39,40}$ In this context, the consensus is wich the components that encourage the patient to speak, that is, frequent RIAS codes associated with open questioning, verbal facilitators and empathic declarations, or those related to the psychosocial dimensions of the patient, result in more patient-focused healthcare. On the other hand, communication with a predominance of closed questions, or a dialogue flow that tends to limit, control or guide patients, is understood as a type of communication that is less focused on the patient's needs, expectations and concerns..$^{11,21-23,27,39}$ Whether the results of a healthcare professional intervention are defined as short-term (e.g. patient satisfaction and their intention to adhere to treatment), medium-term (e.g. adherence to treatment and reduction in patient anxiety) or long-term (e.g. patient quality of life, with recovery and good general health status), the relationship between the health professional's communication characteristics and the patient's state of health is, in fact, one of the most important outcomes to be evaluated. ${ }^{26,31,42}$ RIAS has found a positive association between patient-centered communication, improvement in health results and the reduction of conflicts with professionals. ${ }^{12,36,43} \mathrm{In}$ deed, one of the most common uses of the RIAS has been to study the association between communication and patient satisfaction, where a cause-effect relationship has been confirmed. ${ }^{8,13,32,42}$

With regard to the aspects relating to verbal communication, there are RIAS studies that have identified the verbal dominance of the physician in relation to the patient, with a predominance of technical and biomedical dialogs. ${ }^{710,28,37}$ One study identified that communication for anesthetists was almost biomedical in nature, ${ }^{38}$ while another demonstrated that this communication pattern is more evident in medical interns than specialists. ${ }^{24}$ In relation to other health professionals, such as nurses or those responsible for family planning, the dominance of technical conversation was also verified, ${ }^{27,28,39}$ while for genetic counselors this seems to depend on the context of the consultation. ${ }^{30,31}$ The works described in summary in Table 2 
reveal that in addition to characterizing communication RIAS investigators also studied other factors, such as:

- The perception of respect by the participants in the consultations; 8,13

- The changes of the communication characteristics over time (longitudinal studies); ${ }^{14,15}$

- The impact of training actions on patients and physicians; $;$,11,22,23,28,33

- The reaction of simulated patients; $3,27,29-31$

- Burnout, ${ }^{16,17}$ overwork, ${ }^{18}$ tiredness ${ }^{24}$ or clinical malpractice $^{10}$

- The identification of conflicts ${ }^{12,36}$

- The primary results (e.g satisfaction and the intention to adhere to treatment by the patient), secondary results (e.g changes in the way the patient approaches their health problems) ${ }^{26}$ and treatment decisions; ${ }^{32,35}$

- The use of technical terms ${ }^{7}$ and informed consent (in clinical trials); ${ }^{25,34,44}$

- The approach to matters of a psychosocial nature; ${ }^{19,45}$

- Intercultural differences. ${ }^{20}$

The involvement of various countries and continents ${ }^{2,20,15,38}$ in the studies selected confirm the relevance of this methodology, but potential generalization of the conclusions is limited, given the differences in professional practice and context, from the training of the professionals up to the sociocultural characteristics of the populations.

The studies selected for this review ${ }^{3,7-39}$ aimed only at illustrating the relevance of the RIAS as a method for studying the communication between different health professionals and patients, by exemplifying some of the various approaches to the complex phenomenon of human communication. The studies presented here have enabled the identification of shortcomings in verbal and nonverbal communication by the health professionals involved, such as the absence nonverbal communication, predominance of instrumental communication and dialogs focused on the health professional, lack of patient involvement in discussions and confirmation of their comprehension, and short stimulation of adherence to the prescribed instructions. The RIAS has contributed to accept that understanding the affective, instrumental and nonverbal components of communication permits health professionals to carry out more humanized and, above all, more effective care. The scientific investigation of these communication components, with the use of objective tools such as the RIAS methodology, is not always well accepted by professionals, as well as by other accountable parties, as an important opportunity to monitor and continuously improve the quality of care provided to patients. Nevertheless, the RIAS is one of the instruments delivering objective measurements of the use of communication competencies, which clearly contributes to promote the capacity for diagnosis, clinical efficiency and patient and physician satisfaction, as well as reducing error and emotional difficulties often association with illness and disease. In addition to being an individual responsibility, good communication in the clinical context should also be a responsibility of health organizations, promoting the identification, discussion and continuous training in these competencies. Studies in this area are, in the majority of cases, limited to investigations on a theoretical basis or in a controlled environment (experimental or semi-experimental studies) and not necessarily observational and ecological studies applied to the day-to-day reality of institutions.

In general, various limitations were identified this review, such as the low sample sizes, ${ }^{13,25}$ participation of a limited number of medical sites, ${ }^{21,22,24,32,34}$ few longitudinal studies (in the majority of cases, the data was collected at a single point in time, with eventual implications on results reproducibility), ${ }^{14,15,25}$ studies without the parallel use of other measures for concurrent validity (e.g. questionnaires on the evaluation of the cognitive or satisfaction level of the participants), ${ }^{13}$ etc. All of the above contribute to non generalizable conclusions, frequently constituting evaluations of an exploratory nature. The following were identified as potential bias: the possibility of physician empathic variations based on the socioeconomics class of the patient, ${ }^{13}$ the specific clinical context (public or private clinics, city hospitals, academic medical centers, etc.), ${ }^{3,7,21,25,39}$ the potential to respond in a socially desirable manner to studies complemented by the administration of questionnaires, ${ }^{28}$ and the exact type of events intended to be compared (e.g. pre and postoperative consultations for orthopedic surgery with incapacitating potential vs. other types of surgery). ${ }^{37}$

The conclusions of this review merely intend to constitute an indicator for conducting future studies on communication between patients and health professionals, resulting from the systematization of some of the limitations and potential bias found here. This review did not aim to explore advantages and disadvantages of RIAS in comparison with other methodologies.

\section{Conclusion}

The scientific investigation of communication in healthcare, with the application of specific methodologies such as the RIAS, and the forthcoming of specialists in this 
area would be desirable for the sustainable and harmonious development of health systems. The RIAS methodology has proven to be an important tool for the study of communication between health professionals and patients, contributing to the elaboration of communication effectiveness diagnostics and education guidelines. Therefore, the RIAS has contributed to developing more adequate, effective and humanized communication, thereby defending the final mission of healthcare systems, i.e. human well-being.

\section{RESUMO}

Comunicação entre profissionais de saúde e pacientes: revisão dos estudos que utilizaram o método RIAS (Roter Interaction Analysis System)

Objetivo: rever, de forma sistemática os estudos que investigaram a comunicação entre pacientes e profissionais de saúde através da aplicação da metodologia RIAS.

Métodos: foram utilizados como expressão-chave Roter Interaction Analysis System e os recursos bibliográficos de: Academic Search Complete, Current Contents, ISI Proceedings, PubMed, Elsevier, SpringerLink, Web of Science, RCAAP, Solo e o site oficial do RIAS. Período de seleção: 2006 a 2011. Os estudos foram selecionados por análise dicotômica multicritério e organizados segundo os critérios PRISMA.

Resultados: identificação de 1.262 artigos (455 não repetidos). Foram selecionados para análise 34 artigos, distribuídos pelas seguintes profissões de saúde: médicos de medicina geral e familiar (14), pediatras (5), enfermeiros (4), geneticistas (3), prestadores de cuidados a pacientes com Aids (2), oncologistas (2), cirurgiões (2), anestesistas (1) e especialistas de planejamento familiar (1). O RIAS é escassamente utilizado e divulgado no âmbito dos cuidados de saúde nos países de língua portuguesa.

Discussão: os principais temas estudados incluíram a influência do cansaço, ansiedade e esgotamento profissional na comunicação e o impacto das ações específicas de formação no exercício profissional. A revisão permitiu identificar as principais forças e fraquezas na comunicação verbal, em díade e síncrona na prestação de cuidados de saúde.

Conclusão: a investigação científica da comunicação entre profissionais de saúde e pacientes por meio do RIAS tem produzido resultados concretos. É esperada uma melhoria dos resultados em saúde decorrente da aplicação do RIAS.

Unitermos: RIAS; Roter Interaction Analysis System; comunicação; profissionais de saúde.

\section{REFERENCES}

1. RIASWORKS: Evidence-based communication for education, research \& practice [cited 2011 mar 15]. Available at: http://www.riasworks.com.

2. Roter DL, Larson S. The relationship between residents' and attending physicians' communication during primary care visits: an illustrative use of the Roter Interaction Analysis System. Health Commun 2001; 13:33-48.

3. Sheldon LK, Ellington L, Barrett R, Dudley WN, Clayton MF, Rinaldi K. Nurse responsiveness to cancer patient expressions of emotion. Patient Educ Couns 2009; 76:63-70.

4. Brandão J. Relação e comunicação médico-doente. Rev Port Clin Geral 2008; 24:503-4.

5. Santos I, Ribeiro L. Indicadores de desempenho na consulta. Rev Port Clin Geral 2009; 25:228-36.

6. Prisma: Transparent reporting of systematic reviews and meta-analysis [cited 2011 feb 27]. Available at: http://www.prisma-statement.org/.

7. Greer RC, Cooper LA, Crews DC, Powe NR, Boulware Le. Quality of patientphysician discussions about CKD in primary Care: a cross-sectional study. Am J Kidney Dis 2011; 57:583-91.

8. Beach MC, Roter DL, Wang NY, Duggan PS, Cooper LA. Are physician's attitudes of respect accurately perceived by patients and associated with more positive communication behaviors? Patient Educ Couns 2006; 62:347 54.

9. Haskard B, Williams L, DiMatteo R, Rosenthal R, White K, Goldstein G. Physician and patient communication training in primary care: effects on participation and satisfaction. Health Psychol 2008; 27:513-22.

10. Bensing M, Verheul W, Van Dulmen S. Patient anxiety in the medical encounter: a study of verbal and nonverbal communication in general practice. Health Educ 2008; 108:373-83.

11. Mjaaland TA, Finset A. Communication skills training for genera practitioners to promote patient coping: the GRIP approach. Patient Educ Couns 2009; 76:84-90.

12. Weingarten MA, Guttman N, Abramovitch H, Margalit RS, Roter D, Ziv A et al. An anatomy of conflicts in primary care encounters: a multi-method study. Fam Pract 2010; 27:93-100.

13. Street RL Jr, Gordon H, Haidet P. Physicians' communication and perceptions of patients: Is it how they look, how they talk, or is it just the doctor? Soc Sci Med 2007; 65:586-98.

14. Bensing JM, Tromp F, Van Dulmen S, Van den Brink-Muinen A, Verheul W Schellevis FG. Shifts in doctor-patient communication between 1986 and 2002: a study of videotaped general practice consultations with hypertension patients. BMC Fam Pract 2006; 7:62.

15. Van den Brink-Muinen A, Van Dulmen S, de Haes H, Visser A, Schellevis F, Bensing J. Has patients' involvement in the decision-making process changed over time? Health Expect 2006; 9:333-42.

16. Zantinge E, Verhaak P, Bakker D, Van der Meer K, Bensing J. Does burnou among doctors affect their involvement in patients' mental health problems? A study of videotaped consultations. BMC Fam Pract 2009; 10:60.

17. Ratanawongsa N, Roter D, Beach MC, Laird SL, Larson SM, Carson KA et al. Physician burnout and patient-physician communication during primary care encounters. J Gen Intern Med 2008; 23:1581-8.

18. Zantinge EM, Verhaak PF, de Bakker DH, Kerssens JJ, Van der Meer K Bensing JM. The workload of general practitioners does not affect their awareness of patients' psychological problems. Patient Educ Couns 2007; 67:93-9.

19. Mjaaland TA, Finset A. Frequency of GP communication addressing the patient's resources and coping strategies in medical interviews: a videobased observational study. BMC Fam Pract 2009; 10:49.

20. Van den Brink-Muinen A, Maaroos HI, Tähepõld H. Communication style in primary health care in Europe. Health Educ 2008; 108:384-96.

21. Johnson KB, Serwint JR, Fagan LA, Thompson RE, Wilson ME, Roter D. Computer-based documentation: effects on parent-provider communication during pediatric health maintenance encounters. Pediatrics 2008; 122:590-8.

22. Hart N, Drotar D, Gori A, Lewin L. Enhancing parent-provider communication in ambulatory pediatric practice. Patient Educ Couns 2006; 63:38-46.

23. Wissow L, GadomskiA, Roter D, Larson S, Lewis B, Brown J. Aspects of mental health communication skills training that predict parent and child outcomes in pediatric primary care. Patient Educ Couns 2011; 82:226-32.

24. Liu CC, Wissow LS. Residents who stay late at hospital and how they perform the follow day. Med Educ 2008; 42:74-81. 
25. Greenley RN, Drotar D, Zyzanski SJ, Kodish E. Stability of parenta understanding of random assignment in childhood leukemia trials: an empirical examination of informed consent. J Clin Oncol 2006; 24:891-97.

26. Gilbert DA, Hayes E. Communication and outcomes of visits between older patients and nurse practitioners. Nurs Res 2009; 58:283-93.

27. Langewitz W, Heydrich L, Nübling M, Szirt L, Weber H, Grossman P. Swiss Cancer League communication skills training programme for oncology nurses: an evaluation. J Adv Nurs 2010; 66:2266-77.

28. Kim YM, Heerey M, Kols A. Factors that enable nurse-patient communication in a family planning context: a positive deviance study. Int J Nurs Stud 2008; 45:1411-21.

29. Roter DL, Erby L, Larson S, Ellingtion L. Oral literacy demand of prenatal genetic counseling dialogue: predictors of learning. Patient Educ Couns 2009;75:392-97.

30. Roter DL, Erby LH, Larson S, Ellington L. Assessing oral literacy demand in genetic counseling dialogue: preliminary test of a conceptual framework. Soc Sci Med 2007; 65:1442-57.

31. Roter D, Ellington L, Erby LH, Larson S, Dudley W. The Genetic Counseling Video Project (GCVP): models of practice. Am J Med Genet C Semin Med Genet 2006; 142C:209-20.

32. Kumar R, Korthuis PT, Saha S, et al. Decision-making role preferences among patients with HIV: associations with patient and provider characteristics and communication behaviors. J Gen Intern Med 2010 25:517-23.

33. Beach CM, Wilson I, Saha S et al. Impact of a patient and provider intervention to improve the quality of communication about medication adherence among HIV Patients. Conference abstracts: 5th International Conference on HIV treatment adherence 2010 (Abst. 61339).

34. Daugherty C, Kass NE, Roter DET et al. A study of physician investigator (PI) disclosure of alternatives of care and prognostic information to adVanced cancer patients (ACP) enrolling in phase I trials.ASCO Meeting Abstracts 2009 (Abst. 6508)
35. Siminoff LA, Graham GC, Gordon NH. Cancer communication patterns and the influence of patient characteristics: Disparities in information giving and affective behaviors. Patient Educ Couns 2006; 62:355-60.

36. Levinson W, Roter DL, Mullooly JP, Dull VT, Frankel RM. Physician-patient communication. The relationship with malpractice claims among primary care physicians and surgeons. JAMA 1997; 19:553-9.

37. Levinson W, Chaumeton N. Communication between surgeons and patients in routine office visits. Surgery 1999; 125:127-34.

38. Kindler CH, Szirt L, Sommer D, Hausler R, Langewitz W. A quantitative analysis of anaesthetist-patient communication during the pre-operative visit. Anaesthesia 2005; 60:53-9.

39. Abdel-Tawab N, Roter D. The releVance of client-centered communication to family planning settings in developing countries: lessons from the Egyptian experience. Soc Sci Med 2002; 54:1357-68.

40. Roter D, Larson S. The Roter Interaction Analysis System (RIAS): utility and flexibility for analysis of medical interactions. Patient Educ Couns 2002; 46:243-51.

41. Sondell K, Söderfeldt B, Palmqvist S. Underlying dimensions of verbal communication between dentists and patients in prosthetic dentistry. Patient Educ Couns 2003; 50:157-65.

42. Ong LM, Visser MR, Lammes FB, de Haes JC. Doctor-patient communication and cancer patients' quality of life and satisfaction. Patient Educ Couns 2000; 41:145-56.

43. Rouf E, Chumley H, Dobbie A. Patient-centered interviewing and student performance in a comprehensive clinical skills examination: Is there an association? Patient Educ Couns 2009; 75:11-5

44. Miller VA, Drotar D, Burant C, Kodish E. Clinician-parent communication during informed consent for pediatric leukemia trials. J Pediatr Psychol 2005; 30:219-29

45. Wissow LS, Larson S, Anderson J, Hadjiisky E. Pediatric residents' responses that discourage discussion of psychosocial problems in primary care. Pediatrics 2005; 115:1569-78 